\title{
舌骨過長症の一治験例
}

\author{
本多 徳行・斎藤 等 $\cdot$ 山田武千代 \\ 野田 一郎・大坪 俊雄
}

\section{Hyoid Bone Elongation; A Case Report}

\author{
Noriyuki Honda, Hitoshi Saito, Takechiyo Yamada, \\ Ichiro Noda and Toshio Ohtsubo \\ (Fukui Medical School)
}

\begin{abstract}
We encountered a case of hyoid bone elongation characterized by a clicking sound on swallowing. A 32-year-old man complained of a foreign body sensation and painless clicking sound on the left side of his neck when swallowing. CT scan of the neck revealed that the left greater cornu of the hyoid bone was elongated. Both greater cornu were surgically removed, and his symptoms disappeared.
\end{abstract}

Key words: hyoid bone elongation, clicking sound, foreign body sensation

\section{はじめに}

咽喉頭の異常感を訴える症例の大部分は，原 因のはっきりしない, いわゆる咽喉頭異常感症 である。しかし, なかには咽喉頭の炎症, 良性 腫瘍, 咽喉頭・食道・胃の悪性腫瘍, 舌骨・茎 状突起・頸椎の形態学的異常, アレルギーなど の原因の特定できるものがあり，この場合，原 因となっている器質的な異常の除去が必要とな る. 今回われわれは, 左舌骨大角の形態異常が 原因で，燕下時にクリック音を生じる珍しい咽 喉頭異常感症の一例を経験したのでここに報告 する。

$$
\text { 症例 }
$$

患者 : 32歳, 男性.

主訴：咽喉頭異常感. 與下時の左頸部クリッ ク音.

家族歴：特記すべきことなし.
既往歴 : 特記すべきことなし.

現病歴 : 27 歳頃より, 燕下時に左頸部にクリ ック音を生じる咽喉頭異常感が出現した。 しか し, 咽頭痛・頸部痛や黇下障害などの他の症状 を全く伴わないため, 放置していた. 31歳頃よ りこのクリック音が増強し, 近医耳鼻咽喉科を 受診した. 舌骨, 甲状軟骨, 頸椎などの形態異 常による接触摩擦音を疑い, 精查目的に当科を 紹介され来院した.

初診時所見：身長 $174 \mathrm{~cm}$, 体重 $45 \mathrm{~kg}$ とやや 瘦せ型であるが，全身の骨および関節には特に 異常を認めなかった。扁桃, 舌根部などの咽頭 に異常なく, 喉頭ファイバースコピーによる声 帯, 仮声帯, 梨状陷凹などの観察に掞いても, 特に異常所見は認められなかった. 茎状突起を 触診しても異常はなく, 頸部リンパ節も触れな かった。 
前頸部の視診上, 甲状軟骨, 舌骨に左右差は なかったが，座位にて，與下時に舌骨が挙上し た後下降する時に, 舌骨大角の左側が頸椎横突 起または甲状軟骨に接触して生じると思われる クリック音が認められた。 その際, 左頸部痛や 䐵葆下障害は全く認めなかった。

頸部側面の単純レントゲン写真では, 舌骨や 甲状軟骨の周辺に異常な石灰化を認めず，両者 の位置異常も無かった。

咽・喉頭の腫瘍や嚥下時の通過障害のないこ とを確認するために, 下咽頭頸部食道造影を施 行したが，異常は認められなかった（図 1).

左頸部クリック音が, 舌骨左側大角部の過長 によるものか，左舌骨筋群の拘縮によるもの之 推測し, 頸部 CTを施行した (図 2 ). 舌骨大

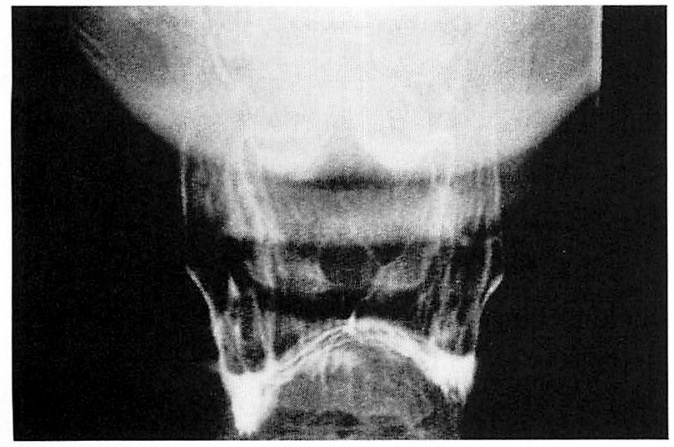

図 1 下咽頭頸部食道造影

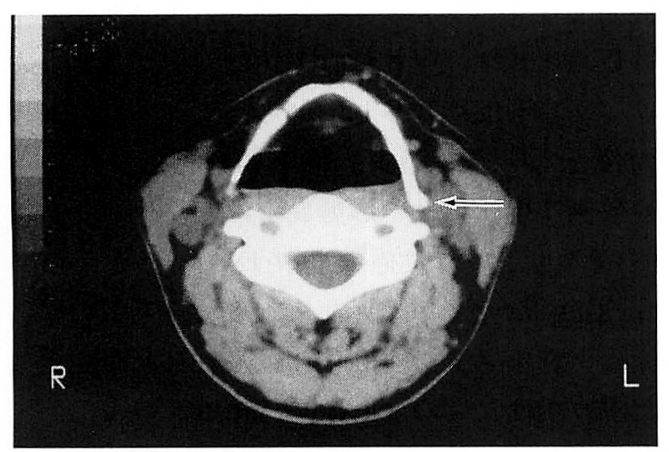

図 2 頸部 CT 所見

舌骨大角部は両側共に過長が認められる. 左側大 角部（矢印）がより過長で内側にやや弯曲.
角部は両側共に過長が認められたが，左側大角 部がより過長で内側にやや弯曲していた。これ が, 頸椎横突起に接触するためにクリック音が 生ずるものと推測した.

この形態異常が主訴の直接的原因と考え, 本 人の強い希望もあることから，全身麻酔下に両 側舌骨大角一部切除術を施行した.

手術：左頸部汇舌骨大角の高さで約 $5 \mathrm{~cm}$ の 皮膚切開を扣き, 広頸筋まで切断, 深頸筋膜に 切開を加え，結合織を剥離し，舌骨大角部を明 視下に打いた，大角部を前方に引出し，大角先 端より甲状舌骨勒帯・甲状舌骨膜 - 中咽頭収縮 筋などの付着筋群・結合織を剥離し，大角部を 露出した. 大角部先端より $2 \mathrm{~cm}$ 程度剥離し, $1.5 \mathrm{~cm}$ の部位で切断した（図 3 ). 舌骨大角の 形態は骨肥厚は認めたものの, 弯曲は少なく, 舌骨付着筋群にも異常は認めなかった。同様な 手技を右頸部にも行い，右舌骨大角を切断摘出 した. 摘出標本では, 左の舌骨大角が右に比べ やや肥厚していた（図 4 ）.

術後経過：手術直後より, 燕下時のクリック 音は消失し, 燕下障害もなく, 咽喉頭異常感も 全く消失した。

\section{考察}

咽喉頭に異常を訴えて来院する患者が近年増 加傾向にあるが，これらのらち「咽喉頭に異常

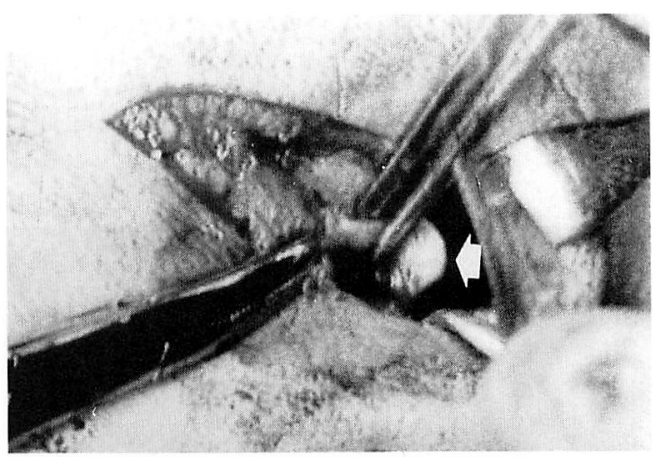

図 3 手術所見

大角部を前方に引出し, 付着筋群 - 結合織を剝離 し，大角部（矢印）を露出. 大角部先端より 2 $\mathrm{cm}$ 程度剥離 $\mathrm{L}, 1.5 \mathrm{~cm}$ の部位で切断. 
を訴えるが通常の耳鼻科的視診によっては，訴 えに見合うような器質的病変を局所に認めない もの」を小池ら ${ }^{1)}$ は咽喉頭異常感症と定義して いる. しかし咽喉頭異常感（症）の原因は多種 多様であり，いわゆる咽喉頭異常感症と診断す るために除外されなければならない基礎疾患は 数多い，そのなかで局所的要因の茎状突起過長， 過長口蓋垂, 舌扁桃肥大, 喉頭蓋異常, 頸椎異 常, 舌骨症候群, 食道息室, など形態異常によ るものはその疾患の存在を知っていれば診断の 難しいものではないと思われる.

しかしながら，今回われわれの経験した症例 は，與下時にクリック音のみを伴う咽喉頭異常 感であり, 嚥下痛, 咽頭痛や頭痛, 頸部痛など の関連痛, 肩こり, しびれ感もなく, 燕下障害, さ声などの諸症状もなかった．この点で，形態 異常から生じる典型的な基礎疾患にあてはまる ものはない，そこでわわわれは敢えて今回の 症例を舌骨過長症と命名した。

すなわち，燕下時にクリック音を左頸部に認 めることから，骨・筋肉系の形態異常由来のも のであることは容易に想像できる，そこで，形 態異常由来の基礎疾患を鑑別診断してみた。 ず画像診断から, 頸椎異常から起こる頸部症候 群2)や Forestier 病3) などや食道㮩室は明らか に否定できた.

片側の咽喉頭の異常感を訴兄, その発生部位 が舌骨大角付近であることが多いものとして， 過長茎状突起症がある4). 別名 Eagle 症候 群5) 7) とも呼ばれる, この過長茎状突起症は

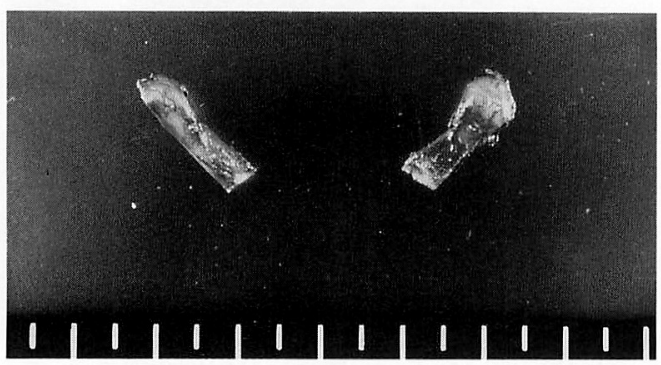

図 4 摘出標本
與下痛や耳痛などを呈する疾患であるが，過長 茎状突起と症状発現の機序との関連は明白では ない。また，この過長茎状突起は必ずしも症状 を伴わないことが知られている8 。 しかし自験 例は，触診や画像診断上，茎状突起の過長も認 めず痛みも一貫して訴觉なかった。この点で, 過長茎状突起症とは考皇にくい.

舌骨拈よび舌骨と関連する組織によって種々 の症状を呈する疾患として舌骨症候群があ $3^{9) 10)}$. これも過長茎状突起症と同じく一側性 の咽喉頭異常感を訴光，大部分の症状に嚥下時 の頸部痛をきたす。そして舌骨の部分切除が症 状の改善をもたらすことも舌骨症候群の診断の 一助になっている11)12). CT にて舌骨左側大角 部の過長を認めた自験例は広義の舌骨症候群か もしれない、しかしながら, 頸部痛, 燕下痛も なく，症候群と言うにはあまりにも症状に乏し く、クリック音のみを呈した報告はない。また， 舌骨症候群に対する診断治療が疼痛軽減を目的 としていることから ${ }^{13)}$ ，今回の症例を舌骨症候 群と呼ぶのは適切ではないと思われた。

一方，燕下時にクリック音を呈する疾患に clicking larynx がある。これは與下時に舌骨と 甲状軟骨が接触し, 頸部痛を伴う異常音（クリ ック音）を生じるものである14)。本邦でも杉田 らが甲状軟骨上角の変形が原因と考光甲状軟骨 上角切除術を施行した，いわゆる clicking larynx を報告した15)。これは，舌骨の形態異常 は認められず，甲状軟骨上角の変形が両側のク リック音形成に関与していると考兄られており， 両例とも ${ }^{14) 15)}$ 頸部痛, 燕下痛を伴っている. 自験例は甲状軟骨の形態異常はなく, 症状も片 側のクリック音で疼痛を伴わないことから， clicking larynx とは異なる。また，與下時のク リック音を呈する症例報告はわれわれが渉隠し た限りでは，この clicking larynx のみであっ た.

自験例は舌骨症候群と clicking larynx の境 界領域に位置するものと考学られるが，両者の どちらにも完全に一致するものではないため, 
自験例を敢えて“舌骨過長症”と命名すること が適切と考えた。

$$
\text { まとめ }
$$

鱟下時クリック音と咽喉頭異常感のみを呈す る舌骨過長症の一症例を報告した。クリック音 は延長した舌骨大角と頸椎横突起との接触によ り生ずることが CT 上示唆され，両側舌骨大角 の切除により，自他覚的に症状が消失した。本 例は文献的に渉诵した限りでは，一致する報告 例はなかった。

本論文の要旨は第 52 回耳鼻咽喉科臨床学会で口演 した.

\section{参考文献}

1）小池靖夫, 文珠敏郎, 戸田雅克, 他 : 咽喉頭異 常感症に対する診断的治療. 耳鼻臨床 72 : 1499 1506, 1979.

2) 大藤敏三，石田 肇：頸部症候群. 耳喉 36 : $1131 \sim 1150,1964$

3）井上鐵三, 沢田正道, 渡辺英男, 他 : Forestier 氏病と嚥下障害. 日耳鼻 $80 ： 1213$ 1215, 1977.

4）岸本誠司, 竹内俊二 : 咽喉頭異常感症の局在診 断. 日気食会報 $38: 343 \sim 347,1987$.

5) Eagle WW and Durham NC : Elongated styloid process; report of two cases. Arch Otolaryngol 25 : 584 587, 1937.

6) Eagle WW, Durham NC : Elongated styloid process ; further observations and a new syndrome. Arch Otolaryngol $47:$ 630 640, 1948.

7) Eagle WW, Durham NC : Symptomatic elongated styloid process ; report of two cases of styloid process, carotid artery syndrome with operation. Arch Otolaryngol 49 : 490 503, 1949.

8）和田哲郎, 草刈 潤, 川島宣義, 他 : CT によ る過長茎状突起症候群の検討. 耳喉頭頸 63 : 355 359, 1991.

9) Brown LA : Hyoid bone syndrome. South Med J 47 : 1088 1091, 1954.

10) Kopstein E : Hyoid syndrome. Arch Otolaryngol $101:$ 484 485, 1975.

11) Bhide AR and Dehadray AY : Excision of the greater cornu of the hyoid in hyoid syndrome. Auris Nasus Larynx $7: 1 \sim 6,1980$.

12）里見文男, 西村善彦, 森 裕司, 他: 舌骨症候 群例. 耳鼻臨床 $84: 359 \sim 362,1991$.

13) Romeo YL : Carotodynia exposed; hyoid bone syndrome. South Med J $80: 444 \sim 446$, 1987.

14) Counter RT : A clicking larynx. J Laryngol Otol 92 : 629 631, 1978.

15）杉田俊明, 森 敏裕, 稲木匠子, 他 : Clicking larynx 例. 耳鼻臨床 $85: 261 \sim 266,1992$.

$\left(\begin{array}{l}\text { 別刷請求先 : 本多徳行 } \\ \overline{\mathbf{T}} 910-11 \text { 福井県吉田郡松岡町下合月 23-3 } \\ \text { 福井医科大学耳鼻咽喉科学教室 }\end{array}\right)$ 